\title{
ЯКОВ НАУМОВИЧ ФЕЛЬД \\ (К 100-ЛЕТИЮ СО ДНЯ РОЖДЕНИЯ)
}

10 марта 2012 г. исполнилост 100 лет со дня рождения крупного ученого в области электродинамики, теории дифракции и теории антенн, доктора технических наук, профессора Якова Наумовича Фельда.

После окончания средней школы в 1927 г., в возрасте 15 лет он поступил на радиофакультет Киевского техникума связи. Уже в этом возрасте он проявил необычайные способности к естественным наукам. После окончания техникума, в 1932 г. Яков Фельд переезжает в Ленинград и начинает свою трудовую деятельность в Центральной радиолаборатории (ЦРЛ). Здесь, благодаря таланту и феноменальному трудолюбию, он получил серьезную моральную поддержку и отеческую заботу о нем от своего руководителя известнгог антеннщика профессора Владимира Васильевича Татаринова. Всю свою жизнь Яков Наумович тепло вспоминал этого замечательного человека. В ЦВЛ началась необычайно плодотворная научная и педагогическая деятельность Я.Н.Фельда, длившаяся свыше 60 лет. С 1932 по 1946 гг. он работал в ЦРЛ, здесь он сформировался как блестящий теоретик с широким научным кругозором, а с 1946 г. и до конца своей жизни заведовал антенным отделом одного из наиболее крупных и авторитетных НИИ министерства радиопромышленности - ЦНИИ-108, г. Москва переименованном впоследствии в Центральный научно-исследовательский радиотехнический институт ЦНИРТИ.

Яков Наумович внес фундаментальный вклад в прикладную электродинамику, в теорию дифракции и в основы современной теории антенн, одним из основателей которой он по праву считается.

Остановимся вкратце на научном наследии Я.Н.Фельда. К числу наиболее важных его научных достижений можно отнести следующее.
1. Формулировка и доказательство ряда общих теорем электродинамики, касающихся различных типов внутренних и внешних краевых задач.

2. Разработка общей теории щелевых (дифракционных) антенн. Фундамент этой теории изложен в известной монографии Я.Н.Фельда «Основы теории щелевых антенн» (1948 г.), являющейся лучшей в мировой литературе по данному вопросу.

3. Развитие известного ранее метода наведенных ЭДС в двух направлениях: создание обобщенного метода наведенных ЭДС и метода магнитодвижущих сил (МДС). Обобщенный метод наведенных ЭДС существенно расширил возможности анализа вибраторных антенн. Использование метода наведенных МДС позволило разработать строгую теорию щелевых антенн, на базе которой развита методика нахождения внутренних и внешних характеристик щелевых антенн, используемая повсеместно при проектировании бортовых и наземных щелевых антенн разнообразных типов.

4. Предложен новый метод решения задач дифракции волн на замкнутых и разомкнутых металлических и импедансных поверхностях. В последнем случае граничные условия могут быть неоднородными и анизотропными. В основе предложенного метода лежит сведение краевой задачи к интегральным уравнениям второго рода. На базе предложенного метода разработана, в частности, эффективная методика расчета параметров зеркальных антенн с вибраторным облучателем, а также методика определения поля рассеяния этой антенны при падении на нее плоской электромагнитной волны. В дальнейшем этот метод был модифицирован в интересах решения трех типов обратных задач, сводящихся к нахождению поверхностных электрического и магнитного токов на заданной 
(замкнутой или разомкнутой) поверхности по известной диаграмме направленности.

5. Разработан метод вариации постоянных для решения краевых задач, сводящихся к уравнениям в частных производных. Предложенный метод весьма перспективен при решении задач рассеяния волн различными телами и определении присущих им эффективных поперечников рассеяния.

6. Детально изучено влияни реальной среды, на работу антенны. Показано, что потери в среде ограничивают максимальную мощность, извлекаемую приемной антенной из падающего поля. Важное практическое значение имеют также полученные Я.Н.Фельдом формулы для мощности, поступающей в приемник при падении на антенну неплоской волны, учитывающие рассогласование на концах фидерного тракта.

7. Разработаны теория рассеяния поля антеннами, работающими на прием, и теория развязки между двумя антеннами, расположенными на некотором расстоянии друг от друга.

Многие теоретические результаты Я.Н.Фельда являются классическими, определившими в значительной мере развитие современной прикладной электродинамики в целом. Основополагающий характер его работ подтверждается в частности и тем, что большая их часть публиковалась в «Докладах АН СССР».

Существенный вклад внесен Я.Н.Фельдом и в создание новой антенной техники. Под руководством и при непосредственном участии Фельда антенным отделом ЦНИИ-108 разработаны многие оригинальные образцы антенной техники - крупные металло-воздушные линзы, антенны поверхностных волн, в том числе антенны на основе ребристых структур, антенны эллиптической поляризации и ряд других антенн. Многие из них нашли практическое применение в разрабатываемых радиосистемах и находятся в эксплуатации до сих пор.

Яков Наумович был не только выдающимся ученым, но и отличным преподавателем.
Преподавательскую деятельность он начал в 1934 г. в Ленинградском институте связи им. М.А.Бонч-Бруевича. Лекции по основам прикладной электродинамики, которые с блеском читал студентам еще совсем юный учитель, с большим интересом и пользой для себя слушали многие уже известные радиоспециалисты. В дальнейшем Яков Наумович вел преподавательскую работу во многих московских вузах. Эту работу он вел до последних дней своей жизни. Исключительный педагогический талант Я.Н. Фельда проявился в его общении как со студентами различных гражданских и военных вузов, так и с участниками многочисленных конференций, семинаров, школ молодых ученых, на которых он выступал в течение всей своей жизни. Особо необходимо выделить Всесоюзный семинар по теории дифракции, который Яков Наумович создал и которым с неиссякаемым энтузиазмом руководил на общественных началах более 35 лет. Через этот регулярно работавший семинар прошли «проверку боем» многие молодые специалисты, ставшие впоследствии видными учеными в различных областях радиофизики. Выступить на «дифракционном» семинаре было и боязно, из-за высокого его научного уровня, и интересно - потому что, благодаря острому уму руководителя семинара, любые спорные и неясные вопросы быстро находили конкретные ответы. Характерной чертой для Якова Наумовича, как руководителя семинара, было сочетание высокой требовательности к докладчикам с очень доброжелательным отношением к ним. Именно последнее способствовало быстрому научному росту многих молодых талантливых людей. В 2001 г. в связи с 90-летием со дня рождения Якова Наумовича, учитывая его огромные заслуги в организации и многолетнем бескорыстном руководстве семинаром было принято решение о присвоении семинару имени Я.Н. Фельда. Это решение было воспринято научной общественностью с большим удовлетворением. 
Важным итогом его многолетней педагогической деятельности явился учебник «Антенны сантиметровых и дециметровых волн», ч. I и II, написанный им совместно с его учеником Л.С.Бененсоном (издан в 1955 и 1959 гг. издательством Военной академии им Н.Е.Жуковского). В этих книгах сочетаются превосходное изложение электродинамических основ теории антенн, базирующееся во многом на оригинальных научных результатах Я.Н.Фельда, с их энциклопедичностью: широким охватом ряда типов антенн сантиметрового и дециметрового диапазонов волн. Фундаментальное рассмотрение принципов построения и теории этих антенн дополнено богатым экспериментальным материалом об их реальных характеристиках. В 2001 г., к 90-летию Якова Наумовича, книга Фельда и Бененсона была переиздана.

Яков Наумович принимал активное участие в подготовке намечавшегося к изданию пятитомного антенного справочника и, в частности, в работе по написанию и редактированию вышедшего в свет в 1997 г. первого тома этого справочника (Изд-во ИПРЖР). Здесь Я.Н.Фельдом дано удивительно компактное и строгое изложение электродинамических основ теории антенн - лучшее из всего известного мне в мировой литературе.

Под руководством Фельда защищено 10 докторских и более 40 кандидатских диссертаций. Он является автором 3-х монографий, более 200 научных работ, 10 авторских свидетельств на изобретения.

На протяжении почти 40 (!) лет Я.Н. Фельд курировал в журнале «Радиотехника и электроника» раздел «Электродинамика, теория дифракции, антенны». При этом ему была свойственна высокая требовательность в конкретных научных вопросах. В 1986 г. Яков
Наумович был удостоен премии им. А.С.Попова АН СССР. Тем не менее, мне, как и многим другим его друзьям и почитателям, представляется, что по его вкладу в развитие электродинамики и общей теории дифракции Яков Наумович был вполне достоин быть избранным в АН СССР. К сожалению, этого не произошло.

Мне выпало большое счастье дружить с Я.Н.Фельдом на протяжении свыше 30 лет и пользоваться его удивительно благожелательным отношением. Это был на редкость честный и глубоко порядочный, благородный человек, высокопринципиальный как в науке, так и в любых жизненных ситуациях, замечательный друг, прекрасный заботливый семьянин. Эти его великолепные человеческие качества в сочетании с удивительным педагогическим мастерством, широчайшей научной эрудицией и огромным творческим потенциалом снискали ему глубокое уважение и любовь огромного числа людей, соприкасавшихся с ним в течение всей его жизни.

Умер Яков Наумович Фельд 28 августа 1995 г.

Прошло уже много времени после ухода из жизни Якова Наумовича, но он по-прежнему с нами. В Москве регулярно, ежемесячно, проводится «фельдовский» дифракционный семинар. И эти семинары, помимо того, что они способствуют дальнейшему развитию теории дифракции и антенн, попутно способствуют тому, чтобы имя основателя этих семинаров Я.Н.Фельда - этого блестящего ученого, выдающегося педагога и замечательного человека - сохранилось на долгие годы в благодарной памяти многих поколений специалистов, занимающихся прикладной электродинамикой.

Доктор технических наук, профессор Я.С.Шифрин 